\title{
New Records of Butterflies from Yap Outer Islands, Micronesia: Fais Island and Ngulu, Ulithi, and Woleai Atolls ${ }^{1}$
}

\author{
Donald W. Buden ${ }^{2,3}$ and W. Fohn Tennent ${ }^{4}$
}

\begin{abstract}
Eight species of butterflies are recorded from among four different island groups in Yap Outer Islands, Federated States of Micronesia (FSM). Five species (63\%) belong to the family Lycaenidae; the three others to Nymphalidae. Hypolimnas bolina is the most ubiquitous species, being the only one recorded on all the islands. Ngulu Atoll, which has the smallest land area, also has one of the most depauperate butterfly faunas, with only two species recorded, but it is located between Palau and Yap proper, which host the richest butterfly faunas in southwestern Micronesia. Ulithi Atoll, which is nearest to potential source populations on Yap, has the largest number of species. Small island size, limited habitat diversity, and lack of sufficient host plants combined with distance from potential source populations are likely to be the main factors contributing to the small number of species on these low-lying coralline islands.
\end{abstract}

Schreiner and Nafus' (1997) guide to the butterflies of Micronesia included all the species known from the Federated States of Micronesia (FSM), but distribution records were for the most part given only as states (i.e.,Yap, Chuuk, Pohnpei, and Kosrae), with no mention of specific islands. Additional locality records for islands and atolls in the FSM were reported by Buden and Miller (2003) and $\mathrm{Bu}-$ den et al. (2005), and all island and atoll locality records for the FSM were included in Tennent's (2006) annotated checklist of butterflies of Oceania. However, many of the small and especially remote, far-flung islands of Micronesia remain unsurveyed or incompletely surveyed biologically, and their butterfly faunas are unknown. In this study we

${ }^{1}$ Manuscript accepted 4 April 2010.

${ }^{2}$ Corresponding author.

${ }^{3}$ Division of Natural Sciences and Mathematics, College of Micronesia-FSM, P.O. Box 159, Kolonia, Pohnpei, Federated States of Micronesia 96941 (e-mail: don_buden@comfsm.fm).

${ }^{4}$ Department of Entomology, The Natural History Museum, London SW7 5BD, United Kingdom (e-mail: jtstorment@gmail.com).

Pacific Science (2011), vol. 65, no. 1:117-122

doi: $10.2984 / 65.1 .117$

(C) 2011 by University of Hawai'i Press

All rights reserved provide the first published reports of butterflies on Fais Island and Ngulu, Ulithi, and Woleai atolls, which are among the outer islands of Yap, in the FSM.

\section{Study Area}

Yap, including the high islands of Yap proper and many widely scattered atolls and low, coralline islands, is one of four states (with Chuuk, Pohnpei, and Kosrae) that compose the island nation of the FSM. The FSM and the Republic of Palau make up the Caroline Islands chain, which spans approximately $3,000 \mathrm{~km}$ of the West-central Pacific Ocean, between the Philippines and Indonesia to the west and the Marshall Islands to the east (Figure 1).

Fais is a raised coral island approximately $28 \mathrm{~m}$ high that was extensively mined for phosphate in the late 1930s and early 1940s, during the Japanese administration (Intoh and Yamaguchi 1996). The interior of the island is a mosaic of open grassy areas, patches of scrubby, xerophytic woodlands, and numerous small garden plots for cultivation of sweet potato (Ipomoea batatas), tobacco (Nicotiana tabacum), several different species of taro (Cyrtosperma merkusii [= chamissonis], Alocasia macrorrbizos, Colocasia esculenta, and Xanthosoma sagittifolium), and other subsistence crops. Remnant patches of semimesic 


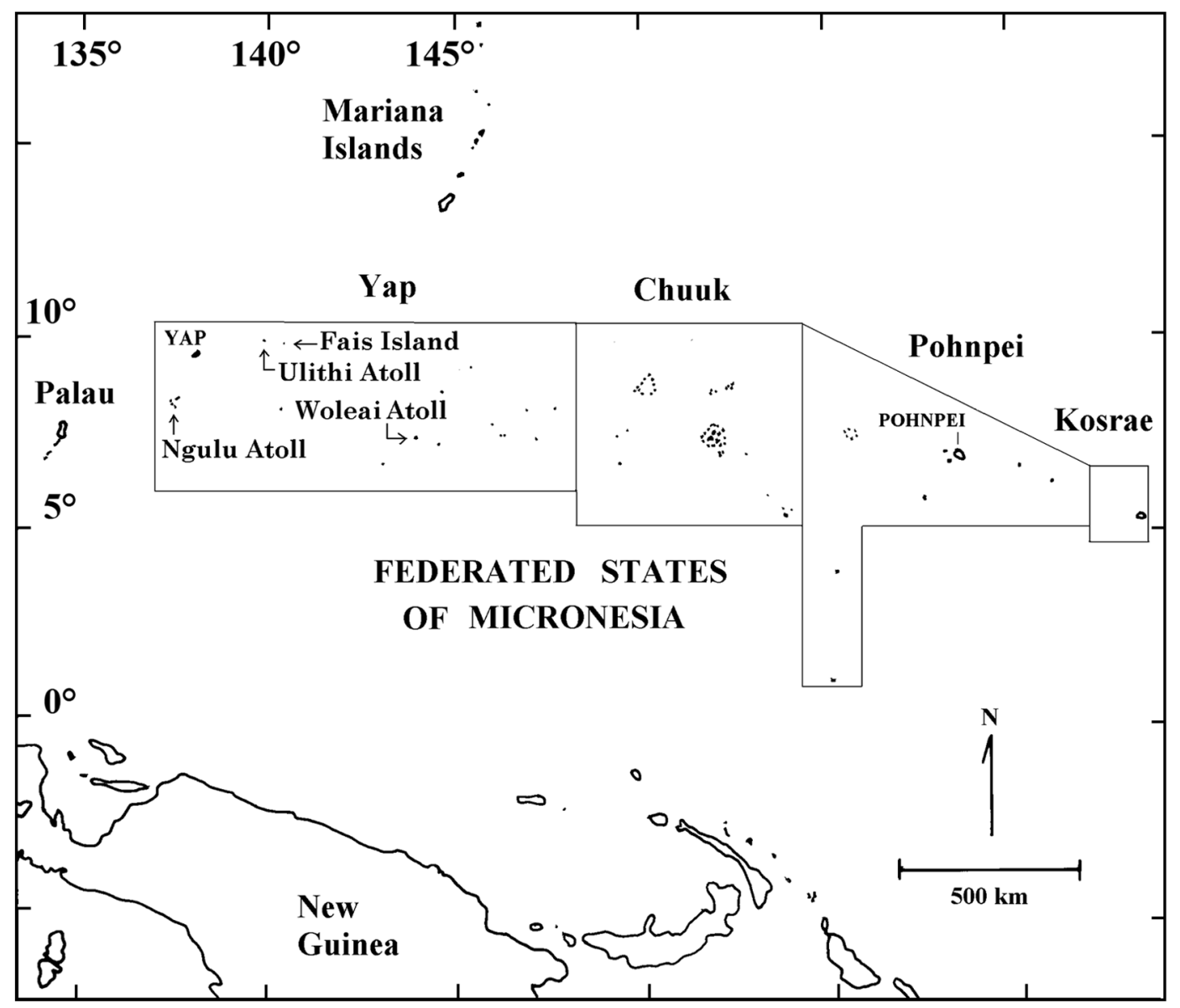

FIGURE 1. Location of Yap State outer islands and surrounding islands.

woodland occur along the rim and at the base of the central plateau. Ngulu, Ulithi, and Woleai are classic atolls that include several to many small, low (ca. 3-5 $\mathrm{m}$ high), predominantly coconut forest-clad islands distributed along a barrier reef enclosing a lagoon. Breadfruit trees (Artocarpus sp.) are often codominant with coconut trees on the larger islands. The forest abuts the beach or is bordered by a narrow zone of coastal thicket composed largely of Scaevola taccada and Tournefortia argentea. Numerous ornamentals and weedy, herbaceous plants are especially common in and around the settlements.

\section{MATERIALS AND METHODS}

Butterflies were collected by D.W.B. on four different island groups in Yap State as part of a project to assess biodiversity: Ngulu Atoll (13 July-9 August 2008, mainly Ngulu Island but including 2 days each on adjacent Ylangchel and Wachuleg islands), Ulithi Atoll (18-21 December 2009), Fais Island (17-21 December 2007 and 23-29 June 2009), and Woleai Atoll (18 June 2009). We also include unpublished records from Ulithi Atoll furnished by K. Tsuda (pers. comm.) and obtained during the 2001 Kagoshima University 
Expedition to Yap and Ulithi (see Tsuda et al. 2003). For simplification we occasionally refer to each atoll as a separate island but acknowledge that each includes several to many islands or islets. Specimens collected were deposited in The Natural History Museum, London. Place names follow Bryan (1971).

\section{SPECIES ACCOUNTS}

Family Lycaenidae

\section{Bindahara phocides (Fabricius)}

This species has been recorded in Micronesia in Palau and Yap [= Yap proper?] (Schreiner and Nafus 1997) and on Falalop, Asor, Mogmog, and Fassarai islands on Ulithi Atoll during the 2001 Kagoshima University Expedition to Yap and Ulithi (unpublished list of species, K. Tsuda, pers. comm.). None was encountered during this study.

\section{Euchrysops cnejus (Fabricius)}

This species is widespread in the Caroline Islands, occurring on all the major island groups. Schreiner and Nafus (1997) recorded it on Palau and Yap, and Buden et al. (2005) provided records from Chuuk, Pohnpei, and Kosrae based on museum specimens collected during the early to mid-1900s. Specimens collected during this study on Ngulu (10), Fais (3 in December, 2 in June), and Ulithi (16) are first island records. It was usually encountered in beach strand, especially where Vigna marina was abundant, and inland in grassy, weedy areas.

\section{Lampides boeticus (Linnaeus)}

This species occurs in Micronesia at least as far east as Chuuk (Schreiner and Nafus 1997). It is unknown from Pohnpei and Kosrae but has been recorded farther to the east in the Marshall Islands (Tennent 2006). It was the most abundant butterfly on Fais Island during mid-December 2007 when several hundred to well over a thousand were seen daily (19 collected); the greatest concentrations were in grassy, shrubby weedy areas, in gardens, and in beach strand. It was common, but less numerous, at the same sites in
June 2009 (six collected), and on Ulithi in December 2009 (five collected).

\section{Zizina labradus (Godart)}

This species is widespread but locally distributed in the FSM and has been recorded on the main islands in Yap, Chuuk, and Pohnpei states (Tennent 2006). The 2001 Kagoshima University Expedition recorded it on Falalop Island, Ulithi, but not on any of the other three islands that were visited, nor on Yap proper (unpublished list of species, K. Tsuda, pers. comm.). None was encountered during this study.

\section{Zizula bylax (Fabricius)}

This species has been recorded from all four of the FSM states, though there are few records from the outer atolls (Tennent 2006). Three specimens collected and three others that were seen along the grassy verge of the airstrip on the day of departure (21 December) were the only ones recorded during the December 2007 visit to Fais. However, it was abundant at the same locality in June 2009, when nine others were collected. This was the most abundant butterfly on Ulithi in December 2009, with thousands being encountered daily in closely cropped grassy areas, often in concentrations of about 5-15/ $\mathrm{m}^{2}$ (11 specimens collected).

\section{Family Nymphalidae Subfamily Danainae}

\section{Euploea eunice Godart}

Schreiner and Nafus (1997) recorded this species in Micronesia from the Mariana Islands, Palau, and Yap. Tennent (2006) considered Caroline Islands records in need of corroboration, and D.W.B. subsequently observed it occasionally on the main island of Yap in 2007 and 2008. One collected in forest and another along a grassy, weedy trail at the edge of forest on Fais Island in December 2007 are the first reported from the island, and the easternmost records for the Caroline Islands; none was observed during the June 2009 visit. A predominantly black butterfly, seen once on Ulithi on 19 December 2009 may have been this species. It was larger 
than $H$. bolina and had slower wing beats, occasionally gliding 1-2 $\mathrm{m}$ between beats as it flew about the crown of a Premna serattifolia tree, about $10-12 \mathrm{~m}$ above the ground.

\section{Subfamily Nymphalinae}

\section{Hypolimnas bolina (Linnaeus)}

This species was common on all the islands and the only butterfly recorded on all four island groups (Table 1). Approximately 25-50 were observed daily on Fais in December 2007 and again in June 2009. During 1821 December 2009, on Falalop Island, Ulithi Atoll, 169 males and 23 females (7:1 ratio) were observed over a period of $390 \mathrm{~min}$ (encounter rate $=30 / \mathrm{hr}$ ). It was most numerous in ruderal habitats in and near the settlements. Only one of the five males collected on Falalop has the broad white median band on the undersurface of the hind wing typical of the species in most Pacific localities. The remaining four specimens have this band largely obscured with dark scales.

\section{Hypolimnas misippus (Linnaeus)}

Schreiner and Nafus (1997:30) recorded this species from Palau and "on Ulithi but not collected from Yap proper." This record almost certainly is based on a female in the

TABLE 1

Statistical Data for Four Groups of Islands in Yap State Included in This Study

\begin{tabular}{lcccc}
\hline \hline Atoll/Island Characteristics & Ngulu Atoll & Ulithi Atoll & Fais Island & Woleai Atoll \\
\hline Number of islands $^{a}$ & $5^{b}$ & 49 & 1 & 22 \\
Total land area $^{a}\left(\mathrm{~km}^{2}\right)$ & 0.427 & 4.66 & 2.80 & 4.53 \\
Largest island $^{a}\left(\mathrm{~km}^{2}\right)$ & 0.12 & 0.94 & 2.80 & 1.53 \\
Distance from Yap proper $(\mathrm{km})$ & 104 & 160 & 220 & 617 \\
Number of islands visited & 3 & 3 & 11 & 1 \\
Observation days & 28 & $8^{d}$ & 5 & 1 \\
Butterfly species $^{c}$ & 2 & & & 1
\end{tabular}

${ }^{a}$ From Bryan (1971) unless otherwise noted.

${ }^{b}$ Data from resident islanders (pers. comm.) and personal observations by D.W.B. Bryan (1971) listed 19, but most are sand and coral rubble cays devoid of vegetation, and many are awash during high seas.

$c$ The total number known from the island, all surveys.

${ }^{d}$ Includes seven identified taxa and one additional unidentified species.

TABLE 2

Distribution of Butterflies among Four Groups of Islands in Yap State, Micronesia

\begin{tabular}{|c|c|c|c|c|}
\hline Species & Ngulu Atoll & Ulithi Atoll & Fais Island & Woleai Atoll \\
\hline \multicolumn{5}{|l|}{ Lycaenidae } \\
\hline Bindahara phocides & & + & & \\
\hline Euchrysops cnejus & + & + & + & \\
\hline Lampides boeticus & & + & + & \\
\hline Zizina labradus & & + & & \\
\hline Zizula bylax & & + & + & \\
\hline \multicolumn{5}{|l|}{ Nymphalidae } \\
\hline \multicolumn{5}{|l|}{ Danainae } \\
\hline Euploea eunice & & $? a$ & + & \\
\hline \multicolumn{5}{|l|}{ Nymphalinae } \\
\hline Hypolimnas bolina & + & + & + & + \\
\hline Hypolimnas misippus & & + & & \\
\hline
\end{tabular}

${ }^{a}$ Sight record, identification uncertain; status hypothetical. 
Bishop Museum collected on Mogmog Island by H. K. Townes on 11 July 1946. There are no other records for Micronesia, although the occurrence of $H$. misippus appears to be highly sporadic elsewhere in the Pacific, including Papua New Guinea (Parsons 1998), the Solomons Archipelago (Tennent 2002), New Caledonia (Tennent 2005), and Vanuatu (Tennent 2009b).

\section{DISCUSSION}

Eight species of butterflies are known from among four of the 15 island groups composing Yap Outer Islands: five lycaenids and three nymphalids. Hypolimnas bolina is the most ubiquitous species, being the only one recorded on all four island groups (Table 1), and the one most likely to be seen on small, remote, coralline islands throughout the Caroline Islands (D.W.B., pers. obs.). That $H$. bolina was the only species recorded on Woleai Atoll, however, may be an artifact of the sampling being limited to just a few hours on 1 day. Conversely, observation of only two species (H. bolina and Euchrysops cnejus) on Ngulu Atoll during 28 consecutive observation days, and on three different islands, probably represents an accurate assessment of butterfly diversity on that atoll, at least for the period of study. Ngulu is located between Palau and Yap proper, which support at least 41 and 21 species, respectively (Schreiner and Nafus 1997, Tennent 2009a,b). Ngulu's depauperate butterfly fauna is probably due chiefly to small island size and limited habitat diversity, including a limited number of potential host plant species.

The largest number of identified species on any one island group is seven on Ulithieight including an unidentified species, possibly Euploea eunice. The relatively large number of species on Ulithi is most likely due to its close proximity to Yap proper. Some of the Ulithi records may pertain to vagrants or strays, as may be the case with solitary observations of $H$. misippus and the unidentified species (see Euploea eunice in Species Accounts). The occurrence of Bindahara phocides on four different islands on Ulithi as recorded by the 2001 Kagoshima University Expedi- tion is more difficult to explain. This species has been recorded in Micronesia only from Palau and Yap (Schreiner and Nafus 1997) but was not encountered by D.W.B. during approximately a total of 5 months on Yap over the past 5 years and during summer and winter seasons. Possibly a breeding or nonbreeding population was present on the atoll (and on Yap proper) for a limited period but has since died out. An accurate assessment of the status of butterfly species diversity among the outer islands of Yap, and on other remote islands throughout Micronesia, requires multiple visits at different times of the year, and probably over several years, to take into account seasonal variation in populations as well as irregular fluctuations due to storms, droughts, and other environmental changes whose effects on the biota are magnified on these miniscule landmasses.

\section{ACKNOWLEDGMENTS}

We thank Chief Mike Ragmau and George Mangthaw on Ngulu Atoll and Santus Saufar and family on Fais for assistance provided to D.W.B. during his visits to their respective islands. We also thank Steve Goodall for providing transportation to Ngulu from Yap aboard the yacht Manta, and Katasuo Tsuda for a list of unpublished records of butterflies from Ulithi Atoll. Al Samuelson, Bernice P. Bishop Museum, Honolulu, kindly provided data from the museum collections on request.

\section{Literature Cited}

Bryan, E. H., Jr. 1971. Guide to place names in the Trust Territory of the Pacific Islands. Pacific Science Information Center, B. P. Bishop Museum, Honolulu. Unpaged.

Buden, D. W., and J. Y. Miller. 2003. The butterflies of Pohnpei, eastern Caroline Islands, Micronesia. Pac. Sci. 57:1-8.

Buden, D. W., D. P. Sands, and W. J. Tennent. 2005. New records of butterflies (Lepidoptera) from the eastern Caroline Islands, Micronesia. Pac. Sci. 59:97103. 
Intoh, M., and Y. Yamaguchi. 1996. An analysis on historic photographs taken on Fais Island in Micronesia during the Japanese period. Hokkaido Tokai Univ. Bull. Humanities Soc. Sci. 9:37-63.

Parsons, M. J. 1998. The butterflies of Papua New Guinea: Their systematics and biology. Academic Press, London.

Schreiner, I. H., and D. M. Nafus. 1997. Butterflies of Micronesia. Agricultural Experiment Station Contribution No. 216. College of Agriculture and Life Sciences, University of Guam, Mangilao.

Tennent, W. J. 2002. Butterflies of the Solomon Islands: Systematics and biogeography. Storm Entomological Publications, Norfolk, England.

. 2005. Some new records of butterflies (Lepidoptera, Papilonoidea) from
New Caledonia, including a new species of Theclinesthes. Futao 49:4, 6-8. 2006. A checklist of the butterflies of Melanesia, Micronesia, Polynesia, and some adjacent areas. Zootaxa 1178:1-209.

- 2009a. A note on the occurrence of Funonia orithya (Linnaeus, 1758) in the Federated States of Micronesia (Lepidoptera, Nymphalidae). Victorian Entomol. 39:6-7.

. 2009b. A field guide to the butterflies of Vanuatu: Ol buttaflae blong Vanuatu. Storm Entomological Publications, Norfolk, England.

Tsuda, K., M. Watanabe, S. Tominaga, M. Onjo, and K. Ichitani. 2003. The biogeography of the insect fauna of Ulithi Islands, Micronesia. Kagoshima Univ. Res. Cent. Pac. Is. Occas. Pap. 39:73-75. 